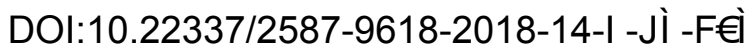

\title{
NATURE SIMILAR TECHNOLOGIES IN CONSTRUCTION INDUSTRY
}

\author{
Valery S. Lesovik ${ }^{1}$, Lilia Kh. Zagorodnyuk ${ }^{1}$, Evgeny S. Glagolev ${ }^{1}$, \\ Natalia V. Chernysheva ${ }^{1}$, Roman S. Feduk ${ }^{2}$ \\ ${ }^{1}$ Belgorod State Technological University named after V.G. Shukhov, Belgorod, RUSSIA \\ ${ }^{2}$ Far Eastern Federal University, Vladivostok, RUSSIA
}

\begin{abstract}
In modern conditions it is necessary to create high-tech, reliable and durable composites of a new generation with the required properties, and this requires qualitatively new approaches in the design, synthesis, operation, destruction and reuse of sources, that is based on the introduction of fundamentally new naturesimiliar technologies. The great interest not only in Russia, but also abroad, present additive technologies.

The article proposes the technology of using water-resistant and cold-resistant quick-hardening composite on the basis of gypsum binders of a new generation with finely ground mineral additives of different genetic types, including using a new unique type of mineral additives - waste from the magnetic separation of ferruginous quartzite.
\end{abstract}

Keywords: bionics, geonics (geomimetics), 3D technologies, additive technologies, composite gypsum binders, mineral additive, construction composites

\section{ПРИРОДОПОДОБНЫЕ ТЕХНОЛОГИИ В СТРОЙИНДУСТРИИ}

\author{
В.С. Лесовик ${ }^{1}$, Л.Х. Загороднюк ${ }^{1}$, Е.С. Глаголев ${ }^{1}$, \\ Н.В. Чернышева ${ }^{1}$, Р.С. Федюк ${ }^{2}$ \\ ${ }^{1}$ Белгородский государственный технологический университет им. В.Г. Шухова, г. Белгород, РОССИЯ \\ 2 Дальневосточный федеральный университет, г. Владивосток, РОССИЯ
}

\begin{abstract}
Аннотация: В современных условиях необходимо создание высокотехнологичных, надежных и долговечных композитов нового поколения с требуемыми свойствами, а для этого необходимы качественно новые подходы при проектировании, синтезе, эксплуатации, разрушении и повторном использовании сырьевых ресурсов, основанные на внедрении принципиально новых природоподобных технологий. Большой интерес не только в России, но и за рубежом представляют аддитивные технологии. В статье предлагается технология использования водостойких и морозостойких быстротвердеющих композиционных гипсовых вяжущих нового поколения с тонкомолотыми минеральными добавками разных генетических типов, в том числе с использованием нового уникального для строительного материаловедения вида минеральных добавок - отходов мокрой магнитной сепарации железистых кварцитов.
\end{abstract}

Ключевые слова: бионика, геоника (геомиметика), 3D-технологии, аддитивные технологии, композиционные гипсовые вяжущие, минеральная добавка, строительные композиты

Currently, humanity is on the threshold of a difficult stage of its development. The new century is characterized by serious problems linked with the depletion of hydrocarbons, the shortage of fresh water, the intensification of natural and manmade disasters, and environmental degradation. Human habitat are deteriorated sharply [1].
It is known that a person spends up to $90 \%$ of his life in an artificially created environment - in rooms built of various building materials, which largely determine the performance, mental activity, creative mood, psycho-emotional state and, finally, the duration of a person's life. 


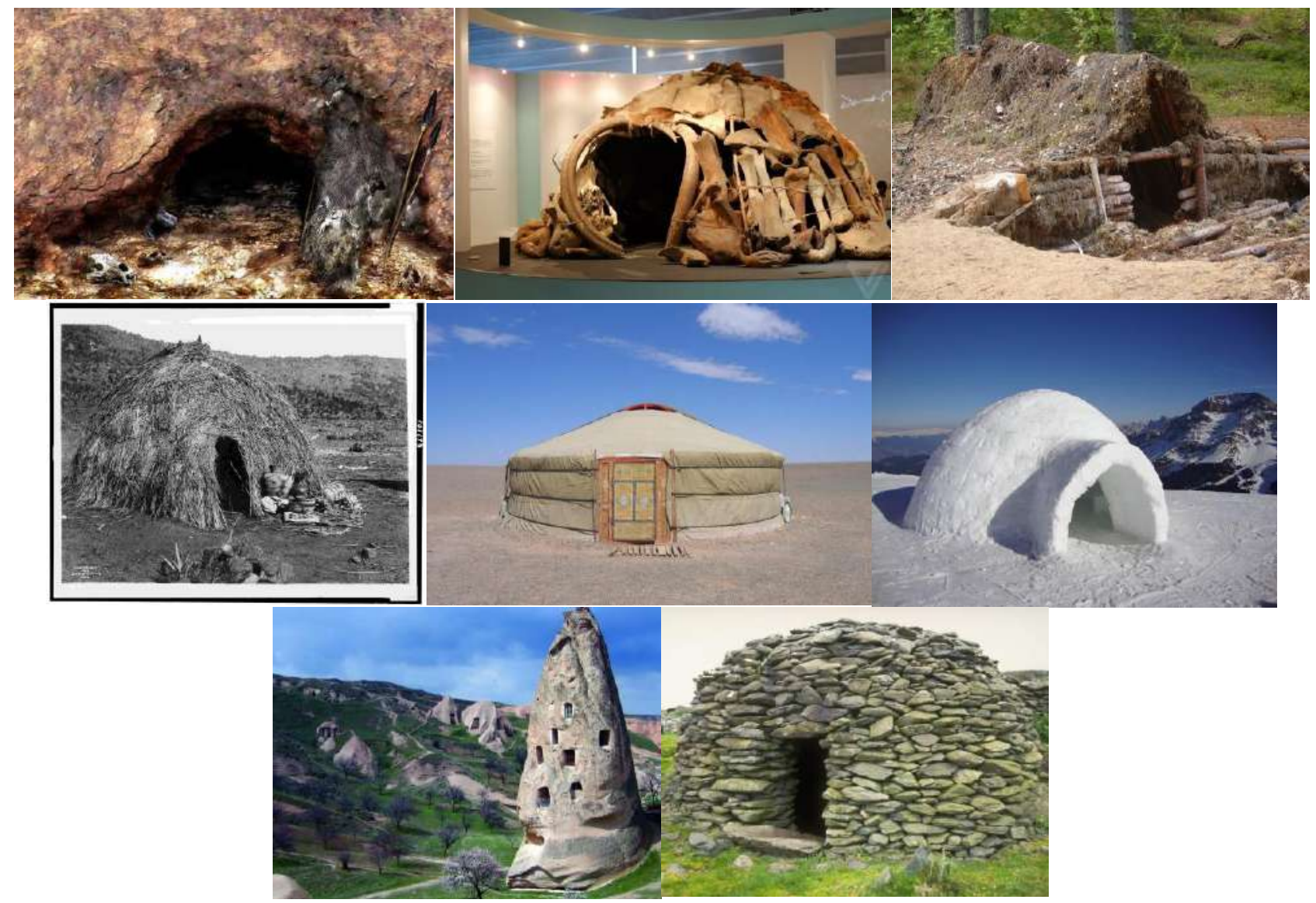

Figure 1. Evolution of human habitation.

The impacts to humans are increased. That manifests itself in the form of cosmic radiation on the human body, which leads to increased fatigue, headaches, irritability. In the course of medical research, it has been established that the prolonged affecting of variable electromagnetic fields on the human body causes disturbances in the cardiovascular and nervous systems. Its manifestation affects to the decrease in performance and reduced accuracy during operation, as well as in accelerated human fatigue. The effect of a variable magnetic field on the human body is manifested in pains in the region of the heart and in headaches.

The vibrations have a negative effect on a person. A progressive increase in the values of the vibrations lead to disruption of the nervous system and rapid fatigue, disruption of the body. Often, people do not think about environmental factors, and their homes do not fit in the surrounding landscape by configuration and form [2].
The solution of such significant problems is possible through the using of a new paradigm of science - the application of transdisciplinary research, which in particular includes cybernetics, bionics, geonics [3-9]. The bionic approach to the study of living nature, and above all the morphology, ecology and physiology of living organisms, their elements and populations, is turned out to be very productive to solve the complex problems of scientific and technological progress.

The organization of the human habitat is determined, above all, the biological need to ensure the conditions of human existence. The formation of the fundamentals of building culture was determined by the natural conditions: the climate of the region, temperature fluctuations, humidity, the nature of the landscape and vegetation, the availability of building materials and others. Depending on the region features, climatic conditions, availability of materials from which it was possible to build up shelters, people created their first homes (Figure 1). 
Valery S. Lesovik, Lilia Kh. Zagorodnyuk, Evgeny S. Glagolev, Natalia V. Chernysheva, Roman S. Feduk
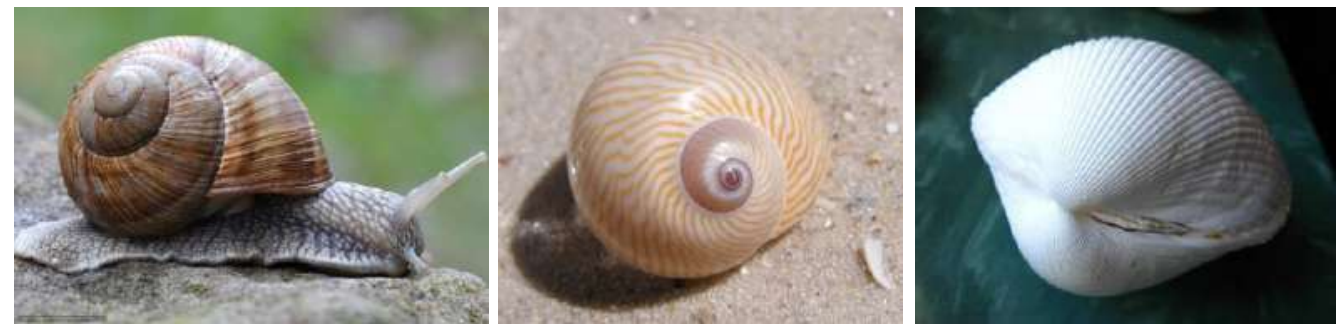

Figure 2. Clams with shells.
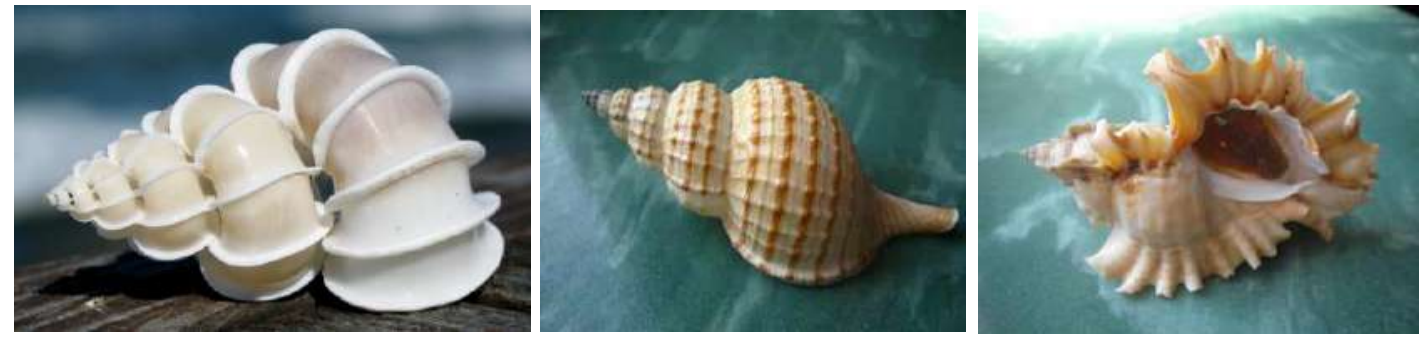

Figure 3. Shellfish Shells.
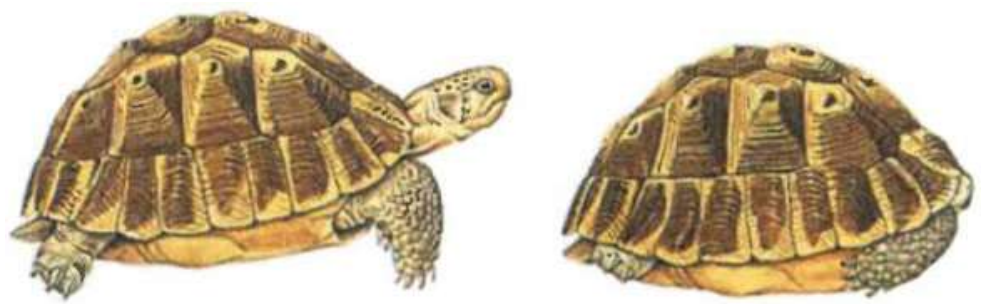

Figure 4. Turtle transformation.
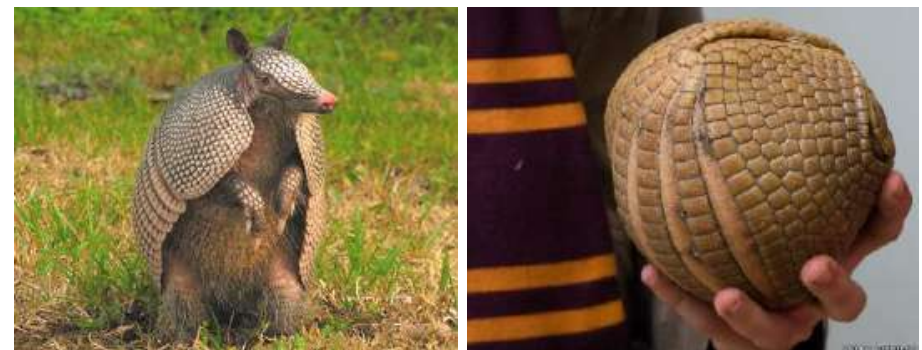

Figure 5. Armadillo Transformation.

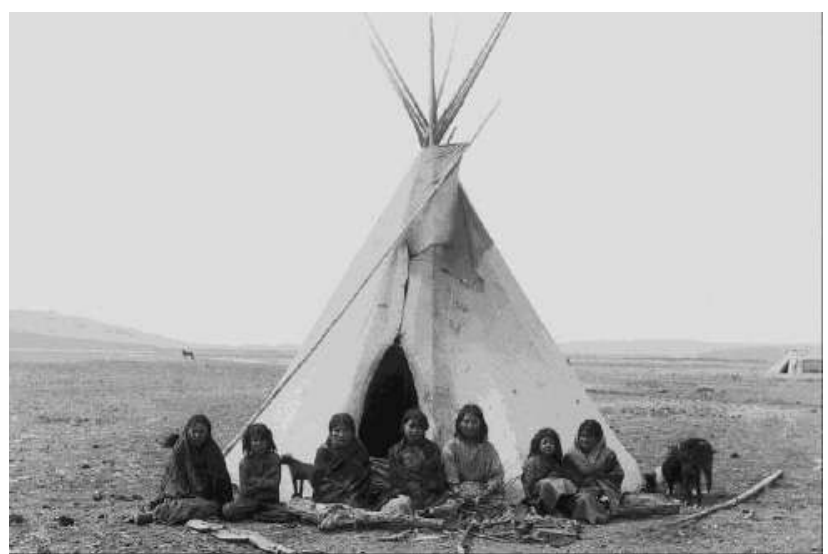

Figure 6. Chum is the dwelling of the humans of the north. 

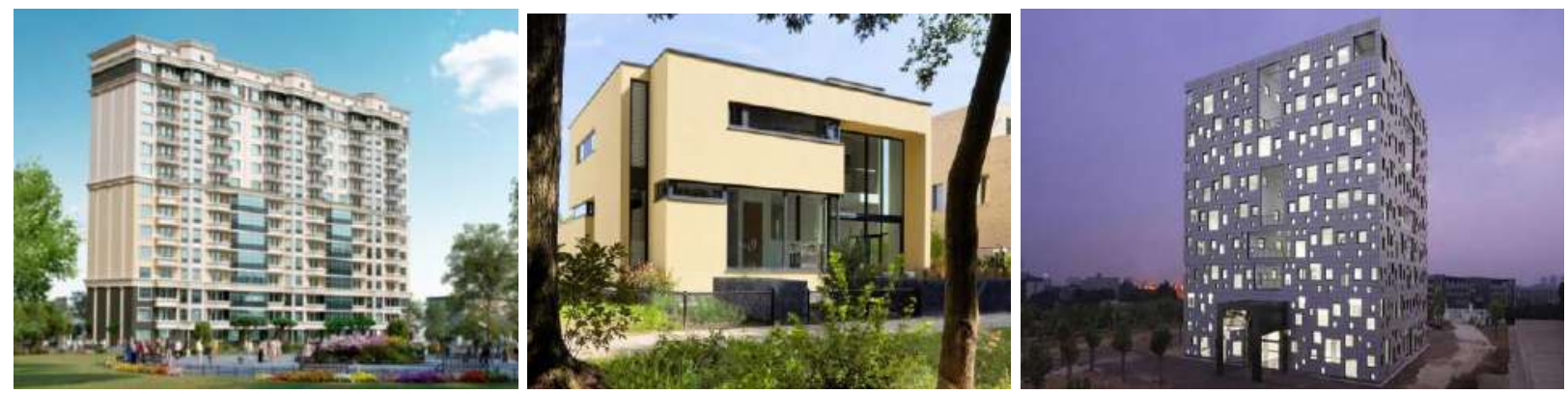

Figure 7. Modern residential buildings.

The configuration of the dwelling deserves special attention. Creating the safe and comfortable dwelling the humanity, since the most ancient times, imitated the animal world and nature and used the protective functions inherent in them (Fig. 2-6).

For the purpose of rational heating, heat preservation and safety, the dwellings were built of a streamlined semi-circular or conical shape, which is chosen by mollusks, foraminifera and fauna representatives for almost a billion-years period of evolution. Until now, the dwellings of northern peoples have a conical form, which provides optimal conditions for keeping warm and comfortable stay of people (Fig. 6).

All historical epochs that had left unique testimonies of human dwellings testify to the imitation of the natural forms of the organic and inorganic world by human. In the early stages, these were oval niches in caves, as the most convenient and comfortable forms for placing a person and preserving heat. Later, the human found that the oval and spherical shapes are the most durable. And human transferred this experience to the construction of dome structures.

Thus, man accepted the billionth experience of the history of the animal world as the basis to create his own shelters and dwellings.

The environment in which we live carries a huge amount of information that negatively affects us. The information coming from human's environment has the greatest influence on the his psyche and thoughts, goals and desires. During the study, certain regularities are found in the relationship between the geometric characteristics of the architectural-spatial form and the psychological response of the person to it (Figure 7).

Humanity appeared on the Earth about 70-50 millennia BC. and from the beginning of its evolutionary accumulated knowledge and improvement of the world. Over time, the sources of knowledge and research methods were differentiated.

The 21 st century requires the creation of modern high-tech structures, reliable and durable composites of a new generation with the required properties, and it requires qualitatively new approaches in the design, synthesis, operation, destruction and reuse of materials based on the introduction of fundamentally new naturesimiliar technologies.

Unfortunately, constructive solutions of buildings and structures at the last centuries switched to the use of vertical and horizontal elements (Figure 7), excluding the billionth experience of living nature.

$3 \mathrm{D}$-additive technologies are the representative card of the modern century. It has great potential in reducing the energy costs for creating a wide variety of products. Despite the many positive features of 3D printing, the introduction of these technologies in Russia has not yet reached a significant level [10-14].

The emergence of 3D printing technology or additive manufacturing is not sudden and it is generally accepted that the foundations of it were laid far in the past. The essence of additive production is summing or technique to create parts of complex shape, when the material is applied sequentially, usually, layer by layer. So it consumes as much as it is necessary to create the required forms. Using of additive production 
technology to construct the buildings and structures, we will significantly reduce costs by reducing material costs and increasing productivity, and will open new creative approaches in the architectural exterior of our cities and create more comfortable conditions for human habitation, that is especially important now.

New constructions should be created taking into account centuries-old building experience. The theoretical basis for the design, development and implementation of these technologies are bionic approaches, the use of the provisions of geonics, the law of the affinity of structures and human-made metasomatism in construction materials.

The theory of technogenic metasomatism in construction materials science, the law of affinity of structures (consisting in designing layered composites, mortars and repair systems, that at the nano, micro and macro levels are similar to the base matrix) are formulated within the framework of theoretical concepts of geonics (geomimetics). The development of new composites should be based on new sources.

The theoretical positions are implemented in the design and synthesis of efficient composites of a new generation based on multicomponent systems with micro, ultra and nano dispersed fillers in combination with other additives.

A whole spectrum of fast-hardening waterproof and frost-resistant composite gypsum binders (Table 1), modified by various types of mineral additives of different genetic types, has been developed [16-17].

To obtain concrete mixtures, that does not decompose to fractions, on the basis of CGB (composites on the basis of gypsum binder) for using at the manufacturing of densely reinforced or thin-walled building products and structures by the technology of layer-by-layer synthesis, the complex chemical additives are used. These additives include setting time retardants, superand hyperplasticities that can provide the ability to control and regulate the structure formation in a plastic state and in the process of forming the structural strength of composites (Table 1).
Finely dispersed fillers with a specific surface area at least $500 \ldots 600 \mathrm{~m} 2 / \mathrm{kg}$, obtained by fine grinding of technogenic sources (waste of magnetic separation of ferruginous quartzites, screenings of quartzitic sandstone, concrete scrap, etc.), of natural resources (silica sand, flask, perlite, tuff, chalk, etc.) contribute to the effective management of the internal structure formation of composites, providing high quality products based on this. A distinctive feature of this raw material is its activation due to air geological processes, which is manifested in the defectiveness of the crystal lattice, the presence of inclusions of the mineral-forming medium and gas-air inclusions, etc. (Figure 8).

The process of forming a single gypsum-cement matrix is also activated due to nucleating agents, which are fine ground concrete scrap and components of the proposed raw materials.

Compounds CGB with microdispersed mineral additives from technogenic raw materials, with reinforcing fibers and complex chemical additives of high water resistance and durability of compressive strength classes B5 - B30, average density D1000-2100 kg / m3, frost resistance $\mathrm{F} 20-\mathrm{F} 50, \mathrm{Kp}=0.65-0.78$ are developed.

The positive properties of gypsum composite materials (low cost, environmental friendliness, rapid curing, good heat and sound insulation properties, absence of shrinkage deformations, good thermal insulation and sound-absorbing ability, fire resistance, a positive effect on people's health by creating a favorable microclimate in the rooms, etc.) allow us to maintain and improve the performance of buildings and the comfort of one's internal environment.

Gypsum composite materials have a great future. The growth rates of it production and applying should be significantly higher than that is for all other building materials. It will allow not only to improve the environmental situation, reduce the energy intensity of the construction industry, but also create comfortable conditions for human existence. The gypsum-containing composite binders are most suitable for use in $3 \mathrm{D}$ additive technologies, due to their unique properties. 
Nature Similar Technologies in Construction Industry

Table 1. Affecting of chemical additives on the properties of CGB (with waste $M S),(W / B=0.46)$.

\begin{tabular}{|c|c|c|c|c|c|c|c|}
\hline \multirow{2}{*}{ Additive type } & \multirow{2}{*}{$\begin{array}{c}\text { Additive } \\
\text { contains in } \\
\text { volume, } \\
\text { mass, } \%\end{array}$} & \multirow{2}{*}{$\begin{array}{l}\text { Spread, } \\
\mathrm{m}\end{array}$} & \multicolumn{2}{|c|}{ Hardening time, min.,sec. } & \multicolumn{3}{|c|}{ Compressive strength, MPa, after } \\
\hline & & & begining & finish & $2 \mathrm{~h}$ & 7 days & 28 days \\
\hline $\begin{array}{l}\text { Without } \\
\text { additives }\end{array}$ & - & $\frac{0,120}{0,180}$ & $\frac{7-40}{8-30}$ & $\frac{9-40}{11-30}$ & $\frac{4,6}{3,2}$ & $\frac{14,8}{13,2}$ & $\frac{20,0}{13,6}$ \\
\hline \multicolumn{8}{|c|}{ based on naphthalene } \\
\hline \multirow{3}{*}{$C-3$} & 0,1 & 0,160 & $8-30$ & $11-30$ & 5,5 & 22,0 & 23,3 \\
\hline & 0,3 & 0,180 & $8-30$ & $11-00$ & 5,1 & 21,5 & 22,0 \\
\hline & 0,5 & 0,220 & $8-20$ & $11-00$ & 4,9 & 19,0 & 20,5 \\
\hline \multirow{3}{*}{$\begin{array}{l}\text { Polyplast } \\
\text { CП-1 }\end{array}$} & 0,1 & 0,160 & $7-45$ & $10-45$ & 5,0 & 14,5 & 15,7 \\
\hline & 0,3 & 0,185 & $7-30$ & $10-30$ & 4,4 & 13,9 & 14,7 \\
\hline & 0,5 & 0,220 & $7-15$ & $10-15$ & 4,2 & 13,4 & 13,9 \\
\hline \multicolumn{8}{|c|}{ melamine based } \\
\hline \multirow{3}{*}{$\begin{array}{l}\text { MELMENT } \\
\quad F 10\end{array}$} & 0,1 & 0,165 & $8-15$ & $11-50$ & 5,8 & 14,4 & 14,7 \\
\hline & 0,3 & 0,195 & $7-45$ & $9-57$ & 4,7 & 13,6 & 13,9 \\
\hline & 0,5 & 0,225 & $7-30$ & $10-35$ & 3,9 & 13,1 & 13,6 \\
\hline \multicolumn{8}{|c|}{ based on resorcinol waste } \\
\hline \multirow{3}{*}{$C Б-3$} & 0,1 & 0,145 & $9-30$ & $12-00$ & 5,4 & 21,0 & 21,7 \\
\hline & 0,3 & 0,200 & $18-00$ & $22-20$ & 3,8 & 19,2 & 20,0 \\
\hline & 0,5 & 0,220 & $25-00$ & $28-30$ & 2,9 & 17,5 & 18,0 \\
\hline \multicolumn{8}{|c|}{ With lemon acid and wastes of it production (CF) } \\
\hline \multirow{3}{*}{ Lemon acid } & 0,03 & 0,160 & $19-15$ & $25-20$ & 4,8 & 9,3 & 10,1 \\
\hline & 0,05 & 0,162 & $24-20$ & $29-00$ & 5,1 & 9,9 & 11,2 \\
\hline & 0,07 & 0,162 & $29-30$ & $34-30$ & 5,6 & 10,4 & 11,9 \\
\hline \multirow{4}{*}{$\begin{array}{l}\text { Citrate filtrate } \\
\qquad(C F)\end{array}$} & 0,3 & 0,120 & $10-30$ & $15-30$ & 5,5 & 17,0 & 17,2 \\
\hline & 0,6 & 0,120 & $15-30$ & $20-00$ & 4,5 & 16,0 & 16,9 \\
\hline & 0,9 & 0,120 & $20-00$ & $25-00$ & 4,2 & 14,2 & 14,5 \\
\hline & 1,5 & 0,120 & $29-00$ & $36-00$ & 3,8 & 11,5 & 13,2 \\
\hline \multicolumn{8}{|c|}{ Complex chemical additives } \\
\hline \multirow{2}{*}{\multicolumn{2}{|c|}{$\begin{array}{l}C-3-(0,5 \%)+Ц \Phi(1,5 \%) \\
C 5-3(0,5 \%+U \Phi(1,5 \%)\end{array}$}} & 0,180 & $45-00$ & $58-00$ & 4,0 & 11,6 & 13,5 \\
\hline & & 0,180 & 53- 00 & $72-00$ & 4,3 & 9,0 & 12,3 \\
\hline \multicolumn{2}{|c|}{$\begin{array}{c}\text { Lemon acid }-(0,05 \%)+ \\
\text { Polyplast } C \Pi-1(0,3 \%)\end{array}$} & 0,265 & $30-00$ & $35-15$ & 4,3 & 13,2 & 13,8 \\
\hline \multicolumn{2}{|c|}{$\begin{array}{l}\text { Lemon acid }(0,05 \%)+ \\
\text { MELMENT F } 10(0,3 \%)\end{array}$} & 0,250 & $30-00$ & $35-30$ & 4,2 & 9,5 & 11,5 \\
\hline
\end{tabular}

Using high-strength composite gypsum binders, respectively, with less weight and reduced matethe quick-hardening reaction-powder concrete reinforced with steel or polymer microfiber has been developed. A feature of this composite is the absence of coarse aggregate without loss in the binder / solid ratio, as well as high performance (concrete stregth ckass is B60 and more). Sand concrete on the reaction-powder binder have a high coefficient of structural quality, that makes it possible to create structures with a rial consumption [15].

The development of building composites, including powder composites, as well as the organization of it production by additive technologies will allow:

- to provide the construction industry with products of complex shape, with high performance; smaller volume as compared to traditional ones, 


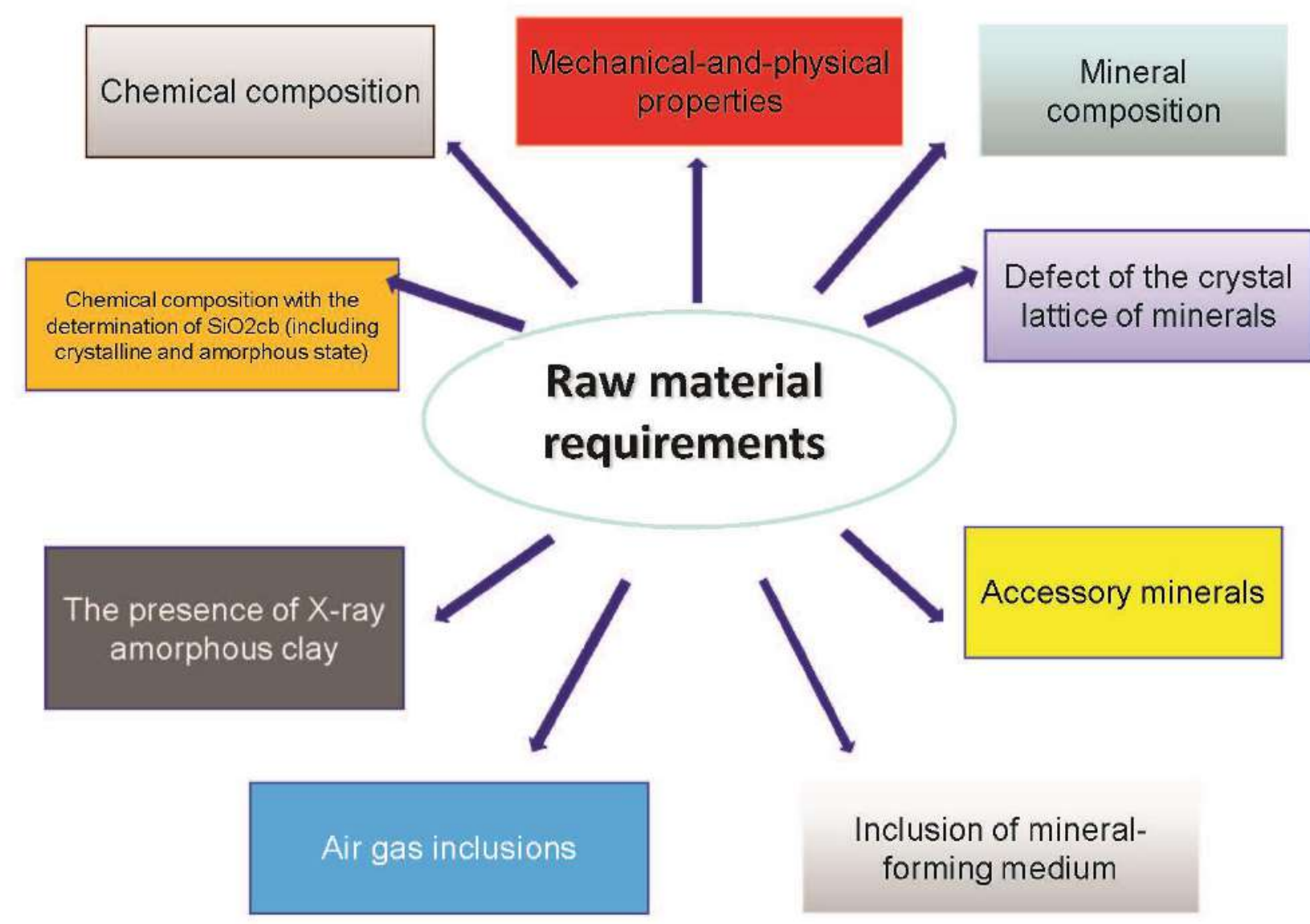

Figure 8. Raw materials requirement.

- exclude technological dependence on the foreign companies-suppliers products for domestic production;

- reduce the cost of manufacturing products of complex shape due to the rejection of expensive machining operations;

- to increase the competitiveness of high-tech products in the international and domestic markets;

- reduce building duration in many times, etc. The introduction of 3D-technologies will allow to build residential buildings comfortable for a human living and having a rational form and configuration similar to the parameters characteristic of the animal world.

Thus, in the modern world, to create a comfortable human environment, it is necessary to develop rational forms of buildings and structures, taking into account the multimillion experience of the biological world, protective systems against negative factors, that is developed by representatives of the organic world. Highly effective quick-hardening systems based on composite waterproof and frost-resistant gypsum binders using new types of raw materials are proposed. Such composites as a result of natural technological activation of rocks due to geological or human-made processes are significantly different from the traditionally used raw materials, i.e. it is genetically activated.

The use of 3D-additive technologies for the construction of buildings and structures will allow to create nature-similiar architectural structures comfortable for human life, able to protect us from negative natural and human-made impacts.

\section{REFERENCES}

1. Telichenko V.I. Ot Ehkologicheskogo i "Zelenogo" Stroitel'stva - k Ehko- 
logicheskoj Bezopasnosti Stroitel'stva [From Ecological and "Green" Construction - to the Ecological Safety of Construction]. // Promyshlennoe i Grazhdanskoe Stroitel'stvo, 2011, No. 2, pp. 47-51.

2. Telichenko V.I. Slesarev M.Yu. Upravlenie Ehkologicheskoj Bezopasnost'yu Stroitel'stva. Ekologicheskaya Ehkspertiza i Ocenka Vozdejstvij na Okruzhayushchuyu Sredu [Management of environmental Safety of Construction. Environmental Impact Assessment and Environmental Impact Assessment]. Moscow, ASV, 2005, 441 pages.

3. Lesovik V.S. Geonics. Subject and Objectives. Belgorod: BSTU, 2012, 100 pages.

4. Lesovik V.S. Geonika (Geomimetika). Primery Realizacii v Stroitel'nom Materialovedenii [Geonics (Geomimetics). Examples of Implementation in the Construction Materials]. Belgorod, Izdatelstvo BGTU, 2016, 287 pages.

5. Lesovik V.S. Tekhnogennyj Metasomatoz v Stroitel'nom Materialovedenii [Man-made Metasomatism in Construction Materials]. // International Proceedings "Stroitel'nye materialy-4S", Novosibirsk, 2015, pp. 2630.

6. Zagorodnuk L.H., Lesovik V.S., Shkarin A.V., Belikov D.A., Kuprina A.A. Creating Effective Insulation Solutions, Takinginto Accountthe Law of Affinity Structures in Construction Materials. // World Applied Sciences Journal, 2013, No. 24(11), pp. 1496-1502.

7. Lesovik V.S., Zagorodnuk L.H., Belikov D.A., Shekina A.Y., Kuprina A.A. Effektivnye Suhie Smesi Dlya Remontnyh i Vosstanovitel'nyh Rabot [Effective Dry Mixes for Repair and Refurbishment]. // Stroitel'nye Materialy, 2014, No. 7, pp. 8285.

8. Lesovik V.S., Zagorodnuk L.H., Tolmacheva M.M., Smolikov A.A., Shekina A.Y., Shakarna M.H.I. StructureFormation of Contact Layers of Composite Materials. // Life Science Journal, 2014, 11(12s), pp. 948-953.
9. Lesovik V.S., Chulkova I.L., Zagordnyuk L.Kh., Volodchenko A.A., Popov D.Y. The Role of the Law of Affinity Structures in the Construction Material Science by Performance of the Restoration Works. // Research Journal of Applied Sciences, 2014, Vol. 9, pp. 1100-1105.

10. Lesovik V.S., Zagorodnuk L.H., Ilinskaya G.G., Belikov D.A. Suhie Stroitel'nye Smesi Dlya Remontnyh Rabot na Kompozicionnyh Vyazhushchih [Dry Construction Mixtures for Repair Work on Composite Binders]. Belgorod, BSTU named after V.G. SHuhov, 2013, 145 pages.

11. Kuprina A.A., Lesovik V.S., Zagorodnyk L.H., Elistratkin M.Y. Anisotropy of Materials Properties of Natural and ManTriggered Origin. // Research Journal of Applied Sciences, 2014, Vol. 9, pp. 816819.

12. Lesovik V.S. Intellektual'nye Stroitel'nye Kompozity Dlya 3D-Additivnyh Tekhnologij [Intellectual Construction Composites for 3D Additive Technologies]. // Proceedings of Scientific-Practical Conference "Effective Building Composites" devoted to the 85th anniversary of the Honored Scientist of the Russian Federation, Full Member of the Russian Academy of Architecture and Construction Sciences, Doctor of Technical Sciences Yuri M. Bazhenov, Belgorod, BSTU named after V.G. SHuhov, 2015, pp. 356-362.

13. Tschernyschowa N.W., Lessowik W.S., Fischer H.B., Drebesgowa M.J. Gips haltige komposit bin demittel - zukunft des ökologischen bauen. // Proceedings of XIX internationale Baustofftagung, Ibausil, 2015, pp. 699-706.

14. Murtazaiev S.A.Y., Saidumov M.S., Lesovik V.S., Chernysheva N.V., Bataiev D.K.S. Fine-Grained Cellular Concrete Creep Analysis Technique with Consideration for Carbonation. // Modern Applied Science, 2015, Vol. 9, No. 4, pp. 233-245. 
15. Chernysheva N.V., Drebezgov D.A. Svojstva i Primenenie Bystrotverdeyushchih Kompozitov na Osnove Gipsovyh Vyazhushchih [Properties and Application of Quick-Hardening Composites Based on Gypsum Binders]. // Vestnik Belgorodskogo gosudarstvennogo tekhnologicheskogo universiteta im. V.G. SHuhova, 2015, No. 5, pp. 125-133.

16. Chernysheva N.V., Lesovik V.S., Drebezgova M.Yu. Vodostojkie Gipsovye Kompozicionnye Materialy s Primeneniem Tekhnogennogo Syr'ya [Waterproof Gypsum Composite Materials Using Technogenic Raw Materials]. Belgorod, BSTU named after V.G. SHuhov, 2015, 321 pages.

17. Tolstoy A.D., Lesovik V.S., Zagorodnuk L.H., Kovaleva I.A. Poroshkovye Betony s Primeneniem Tekhnogennogo Syr'ya [Powder Concretes Using Technogenic Raw Materials]. // Vestnik MGSU, 2015, No. 11, pp. 101-110.

18. Lesovik V.S., Chernysheva N.V., Klimenko V.G. Processy Strukturoobrazovaniya Gipsosoderzhashchih Kompozitov s Uchetom Genezisa Syr'ya [The Processes of Structure Formation of GypsumContaining Composites, Taking into account the Genesis of Raw Materials]. // Izvestiya Vuzov. Stroitel'stvo, 2012, No. 4, pp. 3-11.

19. Chernysheva N.V. Ispol'zovanie Tekhnogennogo Syr'ya Dlya Povysheniya Vodostojkosti Kompozicionnogo Gipsovogo Vyazhushchego [The Use of Technogenic Raw Materials to Improve the Water Resistance of Composite Gypsum Binder]. // Stroitel'nye materialy, 2014, No. 7, pp. 53-56.

\section{СПИСОК ЛИТЕРАТУРЫ}

1. Теличенко В.И. От экологического и «зеленого» строительства - к экологической безопасности строительства. //
Промышленное и гражданское строительство, 2011, №2, с. 47-51.

2. Теличенко В.И. Слесарев М.Ю. Управление экологической безопасностью строительства. Экологическая экспертиза и оценка воздействий на окружающую среду. - М.: АСB, 2005. - 441 с.

3. Lesovik V.S. Geonics. Subjectandobjectives. Belgorod: BSTU, 2012.- $100 \mathrm{c}$.

4. Лесовик В.С. Геоника (геомиметика). Примеры реализации в строительном материаловедении. - Белгород: Изд-во БГТУ, 2016. - 287 с.

5. Лесовик В.С. Техногенный метасомато3 в строительном материаловедении. // Международный сборник научных трудов Строительные материалы-4С. - Новосибирск, 2015, с. 26-30.

6. Zagorodnuk L.H., Lesovik V.S., Shkarin A.V., Belikov D.A., Kuprina A.A. Creating Effective Insulation Solutions, Takinginto Accountthe Law of Affinity Structures in Construction Materials. // World Applied Sciences Journal, 2013, No. 24(11), pp. 1496-1502.

7. Лесовик В.С., Загороднюк Л.Х., Беликов Д.А., Щекина А.Ю., Куприна А.А. Эффективные сухие смеси для ремонтных и восстановительных работ. // Строительные материалы, 2014, №7, с. 82-85.

8. Lesovik V.S., Zagorodnuk L.H., Tolmacheva M.M., Smolikov A.A., Shekina A.Y., Shakarna M.H.I. StructureFormation of Contact Layers of Composite Materials. // Life Science Journal, 2014, 11(12s), pp. 948-953.

9. Lesovik V.S., Chulkova I.L., Zagordnyuk L.Kh., Volodchenko A.A., Popov D.Y. The Role of the Law of Affinity Structures in the Construction Material Science by Performance of the Restoration Works. // Research Journal of Applied Sciences, 2014, Vol. 9, pp. 1100-1105.

10. Лесовик В.С., Загороднюк Л.Х., Ильинская Г.Г., Беликов Д.А. Сухие строительные смеси для ремонтных работ на композиционных вяжущих. - Белгород: 
Издательство БГТУ им. В.Г. Шухова, 2013. - 145 c.

11. Kuprina A.A., Lesovik V.S., Zagorodnyk L.H., Elistratkin M.Y. Anisotropy of Materials Properties of Natural and ManTriggered Origin. // Research Journal of Applied Sciences, 2014, Vol. 9, pp. 816819.

12. Лесовик В.С. Интеллектуальные строительные композиты для 3D-аддитивных технологий. // Сб. трудов «Эффективные строительные композиты». Научнопрактическая конференция к 85-летию Заслуженного деятеля науки Российской Федерации, академика РАACH, доктора технических наук Баженова Юрия Михайловича. - Белгород: БГТУ им. В.Г. Шухова, 2015, с. 356-362.

13. Tschernyschowa N.W., Lessowik W.S., Fischer H.B., Drebesgowa M.J. Gipshaltigekompositbindemittel - zukunftdes ökologischenbauen. // Proceedings of XIX internationale Baustofftagung, Ibausil, 2015, pp. 699-706.

14. Murtazaiev S.A.Y., Saidumov M.S., Lesovik V.S., Chernysheva N.V., Bataiev D.K.S. Fine-Grained Cellular Concrete Creep Analysis Technique with Consideration for Carbonation. // Modern Applied Science, 2015, Vol. 9, No. 4, pp. 233-245.

15. Чернышева, Н.В., Дребезгов Д.А. Свойства и применение быстротвердеющих композитов на основе гипсовых вяжущих. // Вестник Белгородского государственного технологического университета им. В.Г. Шухова, 2015, №5, с. 125-133.

16. Чернышева Н.В., Лесовик В.С., Дребезгова М.Ю. Водостойкие гипсовые композиционные материалы с применением техногенного сырья. - Белгород: Издательство БГТУ, 2015. - 321 с.

17. Толстой А.Д., Лесовик В.С., Загороднюк Л.Х., Ковалева И.А. Порошковые бетоны с применением техногенного сырья. // Вестник МГСУ, 2015, №11, с. 101110.
18. Лесовик В.С., Чернышева Н.В., Клименко В.Г. Процессы структурообразования гипсосодержащих композитов с учетом генезиса сырья. // Известия вузов. Строительство, 2012, №4, с. 3-11.

19. Чернышева Н.В. Использование техногенного сырья для повышения водостойкости композиционного гипсового вяжущего. // Строительные материалы, 2014, № 7, c. 53-56.

Valery S. Lesovik, Corresponding Member of the Russian Academy of Architecture and Construction Sciences, Prof., Dr.Sc., Head of Department of Building Materials, Products and Designs, Belgorod State Technological University named after V.G. Shukhov; 46 Kostyukova street, Belgorod, 308012, Russia; phone +7(4722) 30-99-01; fax +7(4722) 55-71-39;

E-mail: naukavs@mail.ru.

Lilia Kh. Zagorodnyuk, Prof., Dr.Sc., Professor of Department of Building Materials, Products and Designs, Belgorod State Technological University named after V.G. Shukhov; 46 Kostyukova street, Belgorod, 308012, Russia; phone +7(4722) 30-99-01; fax +7(4722) 55-71-39; e-mail: LHZ47@ mail.ru.

Evgeny S. Glagolev, Ph.D., Associated Professor of Department of Civil and Industrial Engineering, Belgorod State Technological University named after V.G. Shukhov; 46 Kostyukova street, Belgorod, 308012, Russia; phone +7(4722) 30-99-01; fax +7(4722) 55-71-39; e-mail: naukavs@ mail.ru.

Natalia V. Chernysheva, Prof., Dr.Sc., Professor of Department of Building Materials, Products and Designs, Belgorod State Technological University named after V.G. Shukhov; 46 Kostyukova street, Belgorod, 308012, Russia; phone +7(4722) 30-99-01;

fax +7(4722) 55-71-39; e-mail: naukavs@ mail.ru.

Roman S. Feduk, Associate Professor of the Educational Military Center, Lieutenant Colonel, Far Eastern Federal University; 8 Sukhanova St., Vladivostok, 690090, Russia; phone 8(800) 555-08-88;

fax +7(423) 243-23-15; e-mail: rectorat@dvfu.ru.

Лесовик Валерий Станиславович, членкорреспондент РААСН, профессор, доктор технических наук; заведующий кафедрой строительного материаловедения, изделий и конструкций, Белгородский государственный технологический университет им. В.Г. Шухова; 308012, Россия, г. Белгород, ул. Костюкова, д. 46; тел. +7(4722) 30-99-01; факс +7(4722) 55-71-39; 
Valery S. Lesovik, Lilia Kh. Zagorodnyuk, Evgeny S. Glagolev, Natalia V. Chernysheva, Roman S. Feduk

E-mail: naukavs@mail.ru.

Загороднюк Лилия Хасановна, профессор, доктор технических наук, профессор кафедры строительного материаловедения, изделий и конструкций, Белгородский государственный технологический университет им. В.Г. Шухова; 308012, Россия, г. Белгород, ул. Костюкова, д. 46;

тел. +7(4722) 30-99-01; факс +7(4722) 55-71-39;

E-mail: LHZ47@mail.ru.

Глаголев Евгений Сергеевич, кандидат технических наук; доцент кафедры промышленного и гражданского строительства, Белгородский государственный технологический университет им. В.Г. Шухова; 308012, Россия, г. Белгород, ул. Костюкова, д. 46; тел. +7(4722) 30-99-01;

факс+7(4722) 55-71-39; e-mail: naukavs@mail.ru.

Чернышева Наталья Васильевна, профессор, доктор технических наук, профессор кафедры строительного материаловедения, изделий и конструкций, Белгородский государственный технологический университет им. В.Г. Шухова; 308012, Россия, г. Белгород, ул. Костюкова, д. 46;

тел. +7(4722) 30-99-01; факс +7(4722) 55-71-39;

E-mail: naukavs@mail.ru.

Федюк Роман Сергеевич, доцент Учебного военного центра, подполковник, Дальневосточный федеральный университет; 690091, Россия, г. Владивосток, ул. Суханова, 8; тел. 8(800) 555-08-88; факс+7(423) 243-23-15; e-mail: rectorat@dvfu.ru. 